\title{
The Effect of Sheet Thickness, Loading Rate and Punch Diameter on the Deformation Behaviour of AZ31 during 3-Point Bending
}

\author{
Franz Berge ${ }^{1, a^{*}}$, Heiko Winderlich ${ }^{1, b}$, Christina Krbetschek ${ }^{1, c}$, \\ Madlen Ullmann ${ }^{1, d}$, and Rudolf Kawalla ${ }^{1, e}$ \\ ${ }^{1}$ Institute of Metal Forming, Technische Universität Bergakademie Freiberg, Bernhard-v.-Cotta-Str. \\ 4, 09599 Freiberg, Germany \\ afranz.berge@imf.tu-freiberg.de, bheiko.winderlich@imf.tu-freiberg.de, \\ cchristina.krbetschek@imf.tu-freiberg.de, ${ }^{d}$ madlen.ullmann@imf.tu-freiberg.de, \\ rudolf.kawalla@imf.tu-freiberg.de
}

Keywords: twin-roll casting, 3-point bending, loading rate, punch diameter, sheet thickness, AZ31.

\begin{abstract}
In this study, the influence of sheet thickness, loading rate, and punch diameter on the bending behaviour of twin-roll cast, rolled and heat-treated AZ31 magnesium alloy was investigated. Therefore, the 3-point bending test was performed at room temperature using an electromechanical testing machine $(\mathrm{v}=0.1-10 \mathrm{~mm} / \mathrm{s})$ with different punch diameters $(\mathrm{D}=2 \mathrm{~mm}, 8 \mathrm{~mm}, 16 \mathrm{~mm})$. The initial material has a recrystallized microstructure with grain sizes of 6-9 $\mu \mathrm{m}$. It is shown by the mechanical investigations that the bending force increases with the sheet thickness. In contrast to this, the bending angle is independent of the sheet thickness. In addition, the punch diameter and the loading rate do not influence the maximum force and the bending angle significantly.
\end{abstract}

\section{Introduction}

The automotive industry strives to reduce the $\mathrm{CO}_{2}$ emissions in the next decades due to statutory specifications [1]. Beside optimized aerodynamics and engines, lightweight design is a major part to fulfil this effort. Magnesium and its alloys offer high specific mechanical properties, good workability, good shock-absorption capacity, and excellent recyclability. Thus, they were brought into focus for the automotive and aerospace constructors.

Large-scale applications are normally formed by deep drawing or stretch forming processes. Individual parts can be produced with specific bending tools. Crucial factors for the part quality are the sheet thickness, loading rate, and the anisotropic deformation behaviour. The sheet thickness dependent 3-point bending behaviour of twin-roll cast (TRC), rolled and heat-treated AZ31 is still unknown for different deformation conditions such as loading rate and punch diameter.

The aim of this article is the examination of the influence of loading rate, punch diameter, sheet thickness, and sample extraction direction on the bending behaviour of AZ31 $(\mathrm{Mg}-3 \mathrm{Al}-1 \mathrm{Zn}-0.3 \mathrm{Mn})$.

\section{Experimental Procedure}

The material used in the experiment was AZ31 $(\mathrm{Mg}-3 \mathrm{Al}-1 \mathrm{Zn}-0.3 \mathrm{Mn})$ magnesium alloy with different sheet thicknesses. The chemical composition is given in

Table 1. The listed conditions represent five different TRC coils. The sheets were produced using the twin-roll casting process. The principle of the TRC process was published in [2-4]. After twin-roll casting process, the homogenization process was undertaken to obtain magnesium sheets with recrystallized microstructure and free of segregations. Subsequently, the sheets were hot-rolled in several passes to produce sheets with various thicknesses of $0.6 \mathrm{~mm}, 0.8 \mathrm{~mm}, 1.0 \mathrm{~mm}, 1.5 \mathrm{~mm}$, and $2.0 \mathrm{~mm}$. Finally, the rolled magnesium sheets were heat-treated for recovery. The whole production process was realized at the Institute of Metal Forming (TU Bergakademie Freiberg). 
Table 1: Nominal chemical composition of the AZ31 alloy used with different sheet thicknesses $\mathrm{t}$ (weight-\%).

\begin{tabular}{|c|c|c|c|c|c|c|c|c|c|c|c|c|}
\hline $\mathrm{t}$ & $\mathrm{Al}$ & $\mathrm{Zn}$ & $\mathrm{Mn}$ & $\mathrm{Zr}$ & $\mathrm{Cu}$ & $\mathrm{Si}$ & $\mathrm{Fe}$ & $\mathrm{Ni}$ & $\mathrm{Ca}$ & $\mathrm{Sn}$ & $\mathrm{Pb}$ & $\mathrm{Mg}$ \\
\hline $0.6 \mathrm{~mm}$ & 2.84 & 1.06 & 0.373 & 0.0014 & $<0.001$ & 0.0246 & 0.0031 & $<0.001$ & $<0,001$ & $<0.005$ & $<0.005$ & bal. \\
\hline $0.8 \mathrm{~mm}$ & 2.84 & 1.03 & 0.374 & 0.0014 & $<0.001$ & 0.0239 & 0.0031 & $<0.001$ & $<0.001$ & $<0.005$ & $<0.005$ & bal. \\
\hline $1.0 \mathrm{~mm}$ & 2.99 & 1.03 & 0.359 & 0.0013 & $<0.001$ & 0.0141 & 0.0029 & $<0.001$ & $<0.001$ & $<0.005$ & $<0.005$ & bal. \\
\hline $1.5 \mathrm{~mm}$ & 2.99 & 1.00 & 0.368 & 0.0015 & $<0.001$ & 0.0151 & 0.0032 & 0.002 & $<0.001$ & $<0.005$ & $<0.005$ & bal. \\
\hline $2.0 \mathrm{~mm}$ & 3.01 & 1.04 & 0.414 & 0.0017 & 0.002 & 0.0176 & 0.0032 & $<0.001$ & $<0.001$ & $<0.005$ & 0.0054 & bal. \\
\hline
\end{tabular}

In order to investigate the deformation behaviour during bending, 3-point bending tests were performed (Fig. 1). Three parallel samples were cut into rectangular pieces according to DIN EN ISO 7438 with a dimension of $120 \mathrm{~mm} \times 20 \mathrm{~mm}$ (length $\times$ width). The bending tests were undertaken at room temperature with different loading rates $(\mathrm{v}=0.1 \mathrm{~mm} / \mathrm{s}, 1 \mathrm{~mm} / \mathrm{s}, 10 \mathrm{~mm} / \mathrm{s})$. Accordingly, a specific test module was installed on the electromechanical test device AG 100 (Shimadzu) in which a semicircular punch with different diameter (D) is used to deform the specimen. The distance between the support rollers is constantly $72 \mathrm{~mm}$. The bending force $\mathrm{F}$ was measured with the $100 \mathrm{kN}$ load cell, whereas the bending angle $\alpha$ was calculated with the deflection measurement system. The measuring accuracy of the load cell is up to $0.1 \%$ (DIN EN ISO 7500-1, class 1 ). The specimens were cut $0^{\circ}$ (parallel) and $90^{\circ}$ (perpendicular) to the rolling direction to investigate the orientation dependent deformation behaviour. Each deformation condition was repeated for three specimens.

For qualitative microstructure investigations, the deformed specimens were investigated in the region perpendicular to the crack by optical microscopy. Therefore, the samples were prepared with a specific route which was explained in [5]. Grain size measurements of the initial materials were performed with the linear intercept method on 500-700 grains in optical micrographs in the area between sheet middle and sheet surface (transition area).
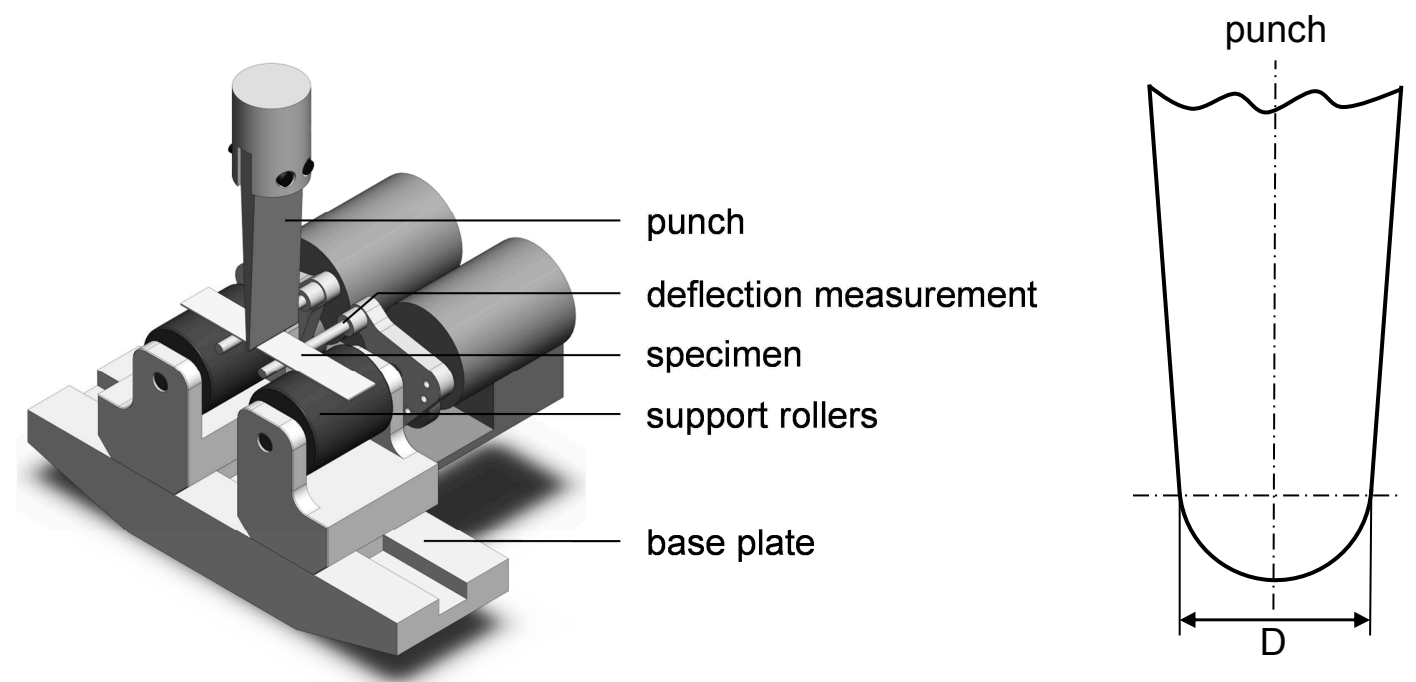

Fig. 1: Principle of the 3-point bending module with corresponding punch geometry.

\section{Results and Discussion}

Material Characterization. The initial material exhibits an equiaxed microstructure with an average grain size of $6 \mu \mathrm{m}(\mathrm{t}=0.6 \mathrm{~mm}), 6 \mu \mathrm{m}(\mathrm{t}=0.8 \mathrm{~mm}), 7 \mu \mathrm{m}(\mathrm{t}=1.0 \mathrm{~mm}), 8 \mu \mathrm{m}(\mathrm{t}=1.5 \mathrm{~mm})$, $9 \mu \mathrm{m}(\mathrm{t}=2.0 \mathrm{~mm})$. Fig. 2 shows exemplarily the microstructure of the $0.6 \mathrm{~mm}$ (a) and the $2.0 \mathrm{~mm}$ (b) sheets. Finely dispersed $\mathrm{Al}_{8} \mathrm{Mn}_{5}$ particles were detected with scanning electron microscopy. In addition, the $\gamma$-phase $\left(\mathrm{Mg}_{17} \mathrm{Al}_{12}\right)$ was dissolved during the homogenization process after TRC. The tensile mechanical properties of the initial AZ31 material with different sheet thickness are 
displayed in Table 2. In general, the strength $\left(\mathrm{R}_{\mathrm{p} 0.2}, \mathrm{R}_{\mathrm{m}}\right)$ values and the elongation to failure $\left(\mathrm{A}_{80}\right)$ are a function of the specimen extraction direction. This might be related to texture and surface effects. In addition, the total deformation varied in the rolling process in order to achieve the final sheet thickness. Higher deformation degrees tend to lower tensile anisotropy in yield strength and elongation to failure, because the probability of favorable oriented grains with regard to the deformation direction rises. This results in larger amounts of dislocation motion in $90^{\circ}$ and $0^{\circ}$ deformation direction. In addition, grain boundary sliding can also occur at room temperature, which leads to higher ductility [6-8]. There is no direct correlation between the anisotropic mechanical properties and the chemical composition.
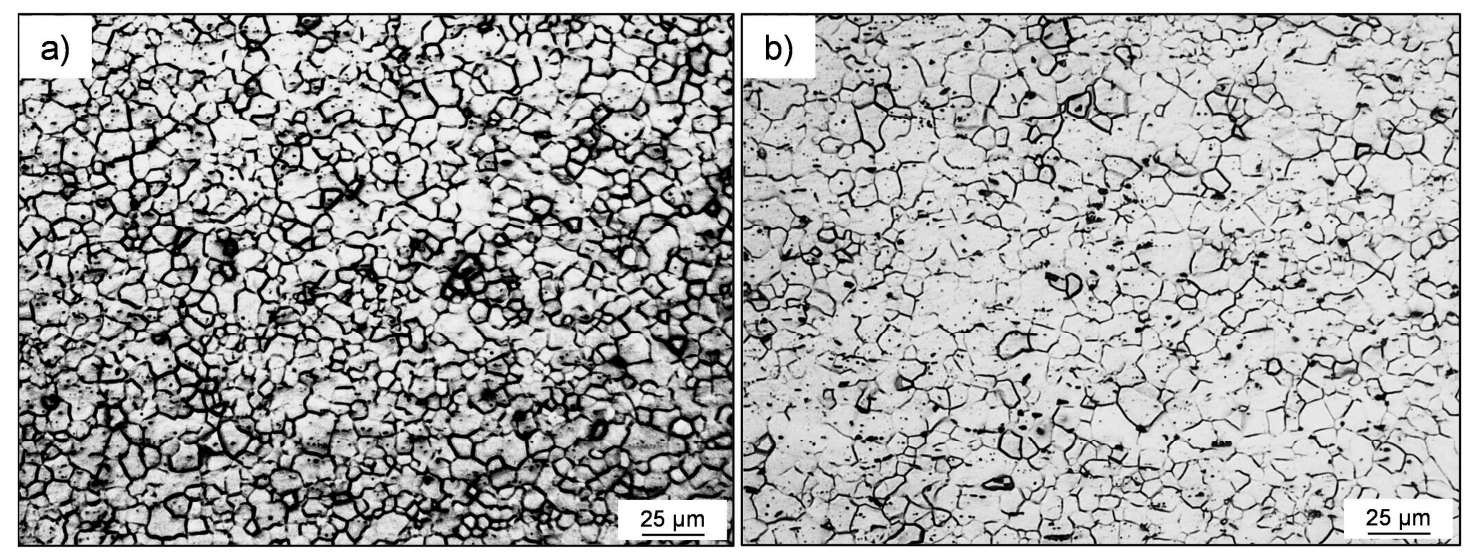

Fig. 2: Optical micrograph of the initial microstructure of the used AZ31 with different thicknesses $\left(0^{\circ}\right)$ : a) $\mathrm{t}=0.6 \mathrm{~mm}$; b) $\mathrm{t}=2.0 \mathrm{~mm}$.

Table 2: Average mechanical properties of the AZ31 alloy used with different sheet thicknesses $t$ under tensile loading (strain rate: $4.17 \times 10^{-4} \mathrm{~s}^{-1}$ ) at room temperature.

\begin{tabular}{|c|c|c|c|c|c|c|c|c|c|}
\hline $\begin{array}{c}\text { Sample } \\
\text { extraction } \\
\text { direction }\end{array}$ & \multicolumn{3}{|c|}{$0^{\circ}$} & \multicolumn{3}{|c|}{$45^{\circ}$} & \multicolumn{3}{|c|}{$90^{\circ}$} \\
\hline $\begin{array}{c}\text { Parameter/ } \\
\begin{array}{c}\text { Sheet } \\
\text { thickness t }\end{array}\end{array}$ & $\begin{array}{c}\mathrm{R}_{\mathrm{p} 0.2} \\
{[\mathrm{MPa}]}\end{array}$ & $\begin{array}{c}\mathrm{R}_{\mathrm{m}} \\
{[\mathrm{MPa}]}\end{array}$ & $\begin{array}{c}\mathrm{A}_{80} \\
{[\%]}\end{array}$ & $\begin{array}{c}\mathrm{R}_{\mathrm{p} 0.2} \\
{[\mathrm{MPa}]}\end{array}$ & $\begin{array}{c}\mathrm{R}_{\mathrm{m}} \\
{[\mathrm{MPa}]}\end{array}$ & $\begin{array}{c}\mathrm{A}_{80} \\
{[\%]}\end{array}$ & $\begin{array}{c}\mathrm{R}_{\mathrm{p} 0.2} \\
{[\mathrm{MPa}]}\end{array}$ & $\begin{array}{c}\mathrm{R}_{\mathrm{m}} \\
{[\mathrm{MPa}]}\end{array}$ & $\begin{array}{c}\mathrm{A}_{80} \\
{[\%]}\end{array}$ \\
\hline $0.6 \mathrm{~mm}$ & 167 & 254 & 25 & 177 & 256 & 24 & 185 & 258 & 21 \\
\hline $0.8 \mathrm{~mm}$ & 175 & 253 & 23 & 183 & 256 & 25 & 191 & 260 & 23 \\
\hline $1.0 \mathrm{~mm}$ & 195 & 267 & 25 & 200 & 267 & 28 & 207 & 269 & 25 \\
\hline $1.5 \mathrm{~mm}$ & 165 & 255 & 26 & 165 & 254 & 26 & 167 & 256 & 25 \\
\hline $2.0 \mathrm{~mm}$ & 178 & 264 & 27 & 171 & 260 & 28 & 170 & 261 & 20 \\
\hline
\end{tabular}

Influence of Sheet Thickness, Loading Rate and Punch Diameter on the Direction Dependent Bending Behaviour. During 3-point bending, the force rises up to the force maximum where after crack initiation and propagation occurs (Fig. 3). This leads to a significant force drop.

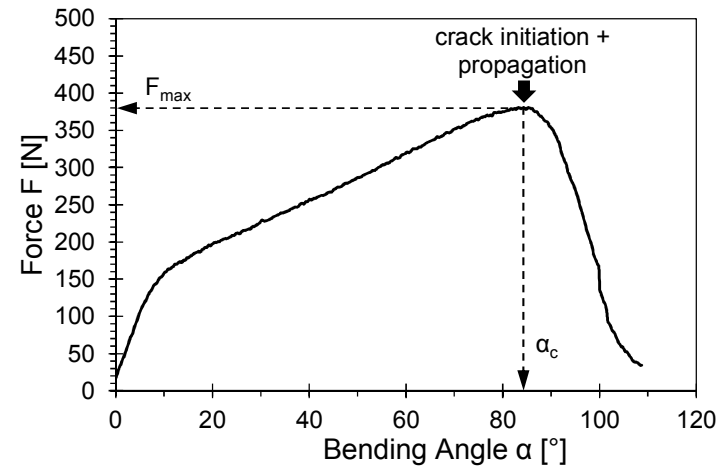

Fig. 3: Example of a force vs. bending angle curve with necessary parameters. 
The influence of the sheet thickness $(\mathrm{t})$, loading rate $(\mathrm{v})$, and punch diameter (D) on the force maximum $\left(\mathrm{F}_{\max }\right)$ and the corresponding bending angle $\left(\alpha_{\mathrm{c}}\right)$ is displayed in Fig. $4 \mathrm{a}-\mathrm{c}$.
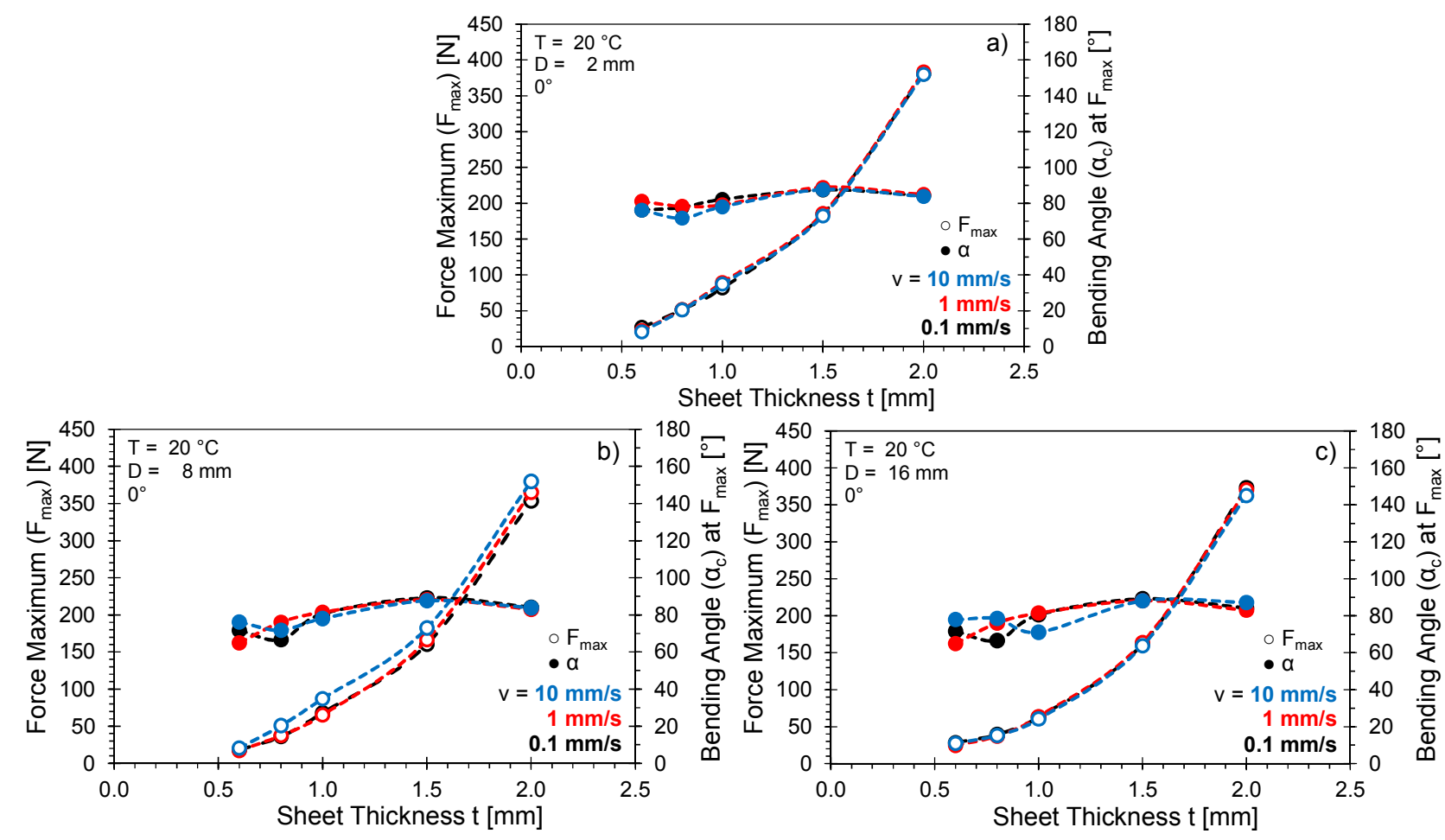

Fig. 4: $\mathrm{a}-\mathrm{c})$ Force maximum $\left(\mathrm{F}_{\max }\right)$ and bending angle $\left(\alpha_{c}\right)$ at $\mathrm{F}_{\max }$ for different sheet thicknesses $(\mathrm{t}=0.6 \mathrm{~mm}, 0.8 \mathrm{~mm}, 1.0 \mathrm{~mm}, 1.5 \mathrm{~mm}, 2.0 \mathrm{~mm})$, loading rates $(\mathrm{v}=0.1 \mathrm{~mm} / \mathrm{s}, 1.0 \mathrm{~mm} / \mathrm{s}, 10 \mathrm{~mm} / \mathrm{s})$ as a function of the punch diameter $(\mathrm{D}=2 \mathrm{~mm}, 8 \mathrm{~mm}, 16 \mathrm{~mm})$ at room temperature 3-point bending deformation $\left(0^{\circ}\right)$.

It can be seen that $\mathrm{F}_{\max }$ rises with increasing sheet thickness because the deformation volume is enlarged. In addition, the moment of resistance to bending extends with increasing sheet thickness. In contrast, $\alpha_{c}$ remains nearly constant as the sheet thickness and deformation conditions are changed. The described deformation behaviour is applicable for all punch diameters. There is no significant influence of $\mathrm{D}$ and $\mathrm{v}$ on $\mathrm{F}_{\max }$ or $\alpha_{c}$. In the study of Li et al. [9], a positive influence of the loading rate on $\mathrm{F}_{\max }$ and $\alpha_{\mathrm{c}}$ is pronounced. The spread of the $\alpha_{\mathrm{c}}$ values decreases considerably above $1.0 \mathrm{~mm}$ sheet thickness. Furthermore, there is no direct correlation between the bending values and the chemical composition.

The influence of the sample extraction direction on the bending behaviour is displayed in Fig. 5 as a function of the sheet thickness, loading rate, and punch diameter. At a punch diameter of $2 \mathrm{~mm}$ and $8 \mathrm{~mm}$, the force maximum in $90^{\circ}$ direction is generally below the $\mathrm{F}_{\max }$ values in $0^{\circ}$ direction at sheet thicknesses above $1.0 \mathrm{~mm}$. This is in contrast to the investigations of Kim et al. [10] on conventional rolled AZ31 sheets, where $90^{\circ}$ is the stronger direction. The anisotropic behaviour in the present study is typical for TRC AZ31, because it might be related to texture effects [11]. At a punch diameter of $16 \mathrm{~mm}$, this difference $\left(0^{\circ}-90^{\circ}\right)$ is only pronounced at $\mathrm{t}=2.0 \mathrm{~mm}$. Furthermore, the bending angle at $F_{\max }\left(\alpha_{c}\right)$ is independent of the sample extraction direction and punch diameter. 

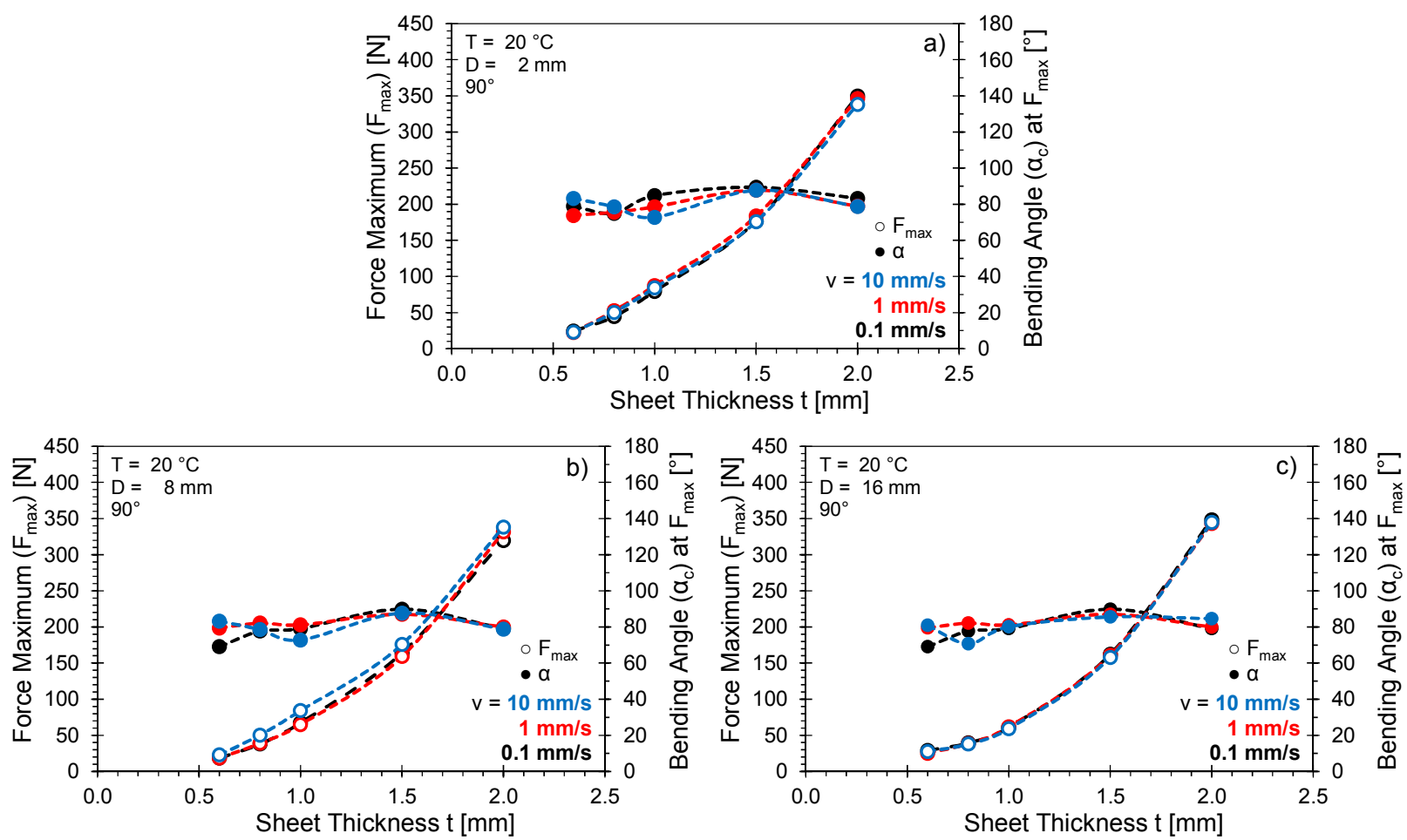

Fig. 5: a-c) Force maximum $\left(F_{\max }\right)$ and bending angle $\left(\alpha_{c}\right)$ at $F_{\max }$ for different sheet thicknesses $(\mathrm{t}=0.6 \mathrm{~mm}, 0.8 \mathrm{~mm}, 1.0 \mathrm{~mm}, 1.5 \mathrm{~mm}, 2.0 \mathrm{~mm})$, loading rates $(\mathrm{v}=0.1 \mathrm{~mm} / \mathrm{s}, 1.0 \mathrm{~mm} / \mathrm{s}, 10 \mathrm{~mm} / \mathrm{s})$ as a function of the punch diameter $(\mathrm{D}=2 \mathrm{~mm}, 8 \mathrm{~mm}, 16 \mathrm{~mm})$ at room temperature 3-point bending deformation $\left(90^{\circ}\right)$.

The microstructure of the deformed specimens are displayed in Fig. 6 for $\mathrm{t}=0.6 \mathrm{~mm}$ and $\mathrm{t}=2.0 \mathrm{~mm}$ at different loading rates. The optical micrographs represent the area adjacent to the fracture surface. At sheet thickness $\mathrm{t}=0.6 \mathrm{~mm}$ and loading rate of $0.1 \mathrm{~mm} / \mathrm{s}$ (Fig. $6 \mathrm{a}$ ), equiaxed and nearly twin-free grains are present. The microstructure exhibits the generation of mechanical twinning especially in larger grains $(\mathrm{d}>10 \mu \mathrm{m})$ when the loading rate rises to $10 \mathrm{~mm} / \mathrm{s}$ (Fig. $6 \mathrm{~b}$ ). This behaviour is also visible with sheet thickness of $\mathrm{t}=2.0 \mathrm{~mm}$ (Fig. $6 \mathrm{c}$ and $\mathrm{d}$ ) with the difference compared to $\mathrm{t}=0.6 \mathrm{~mm}$ that twinning is also apparent in the lower loading rate of $0.1 \mathrm{~mm} / \mathrm{s}$. The average grain size is higher for samples with sheet thickness of $t=2.0 \mathrm{~mm}(9 \mu \mathrm{m})$ than in samples with sheet thickness of $\mathrm{t}=0.6 \mathrm{~mm}(6 \mu \mathrm{m})$, which is a positive driving force for mechanical twinning. Mechanical twinning can cause a Hall-Petch-like hardening effect by the twinning induced reduction of the free path length of moving dislocations [12]. Furthermore, the grain reorientation during twinning can lead to lower or higher Schmid factors for basal slip within the twin, which can also increase the hardening behaviour [13]. If the twins deform as a result of high Schmid factors (basal slip), stress concentrations can occur in the area of the grain-twin boundary. In particular, some grains are divided several times by twins when the amount of twins is higher (Fig. $6 \mathrm{~b}$ and d). It has been suggested that these twins are $\{10-12\}<10-1-1>$ extension twins because of their low critical resolved shear stress in comparison to $\{10-11\}<10-1-2>$ compression twins $[2,14]$. It can be noted that there are no distinctive localized twin bands in the compression zone like in the study of Li et al. [15].

The influence of the sample extraction direction $\left(0^{\circ}, 90^{\circ}\right)$ on the microstructure near the fracture surface is shown in Fig. 7. In comparison to Fig. 6, it can be seen that at $90^{\circ}$ deformation and a sheet thickness of $0.6 \mathrm{~mm}$ (Fig. $7 \mathrm{a}$ ), a rise in loading rate (Fig. 7 b) does not increase the amount of mechanical twinning. At $\mathrm{t}=2.0 \mathrm{~mm}$, the positive influence of loading rate on the mechanical twinning is nearly the same as at $0^{\circ}$ deformation. 

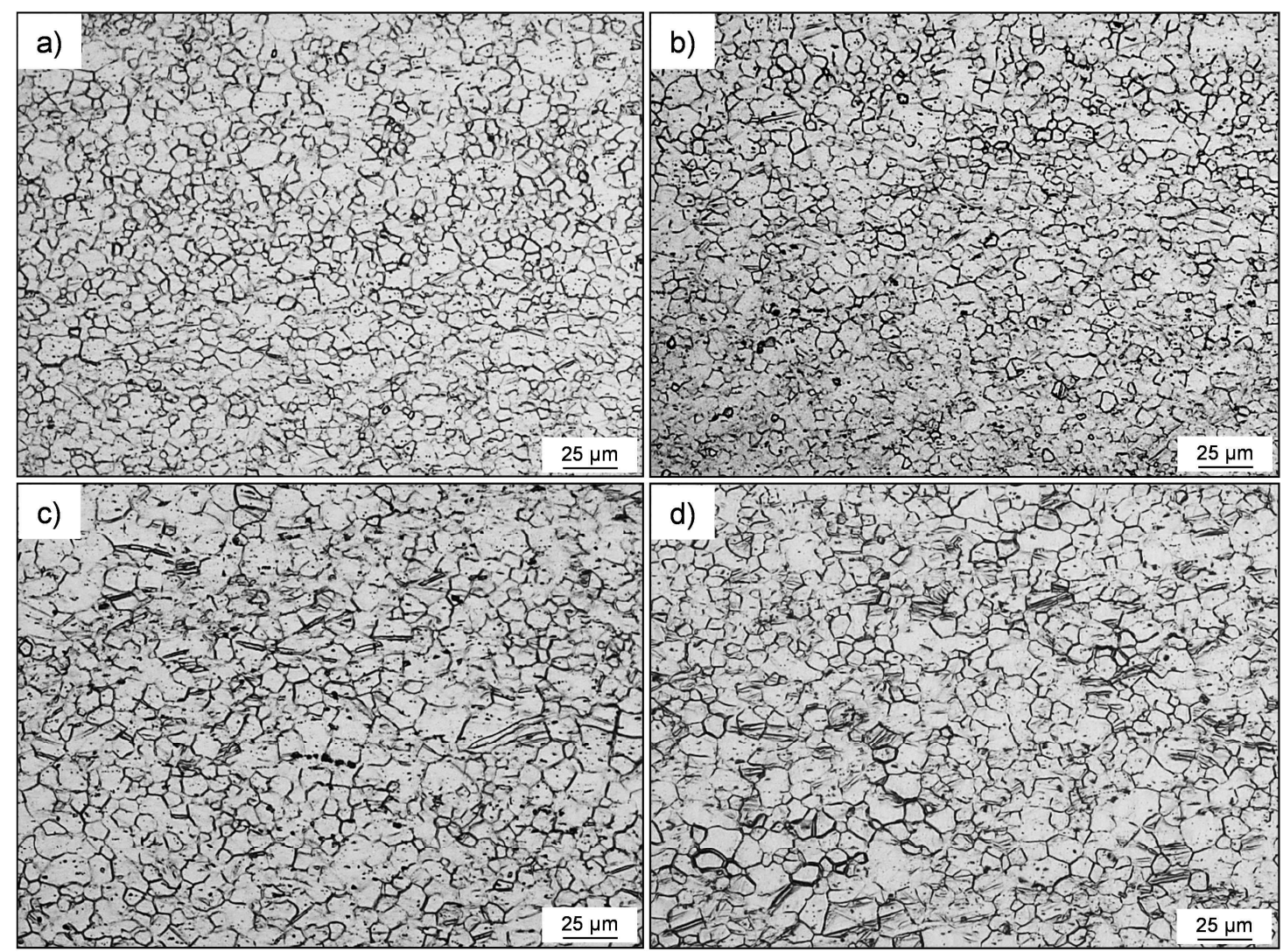

Fig. 6: Optical micrograph of the fractured specimens in the region of the crack at different bending conditions with different thicknesses $\left(0^{\circ}\right)$ : a) $\left.\mathrm{t}=0.6 \mathrm{~mm}, \mathrm{v}=0.1 \mathrm{~mm} / \mathrm{s} ; \mathrm{b}\right) \mathrm{t}=0.6 \mathrm{~mm}, \mathrm{v}=10 \mathrm{~mm} / \mathrm{s}$; c) $\mathrm{t}=2.0 \mathrm{~mm}, \mathrm{v}=0.1 \mathrm{~mm} / \mathrm{s} ; \mathrm{d}) \mathrm{t}=2.0 \mathrm{~mm}, \mathrm{v}=10 \mathrm{~mm} / \mathrm{s}$.
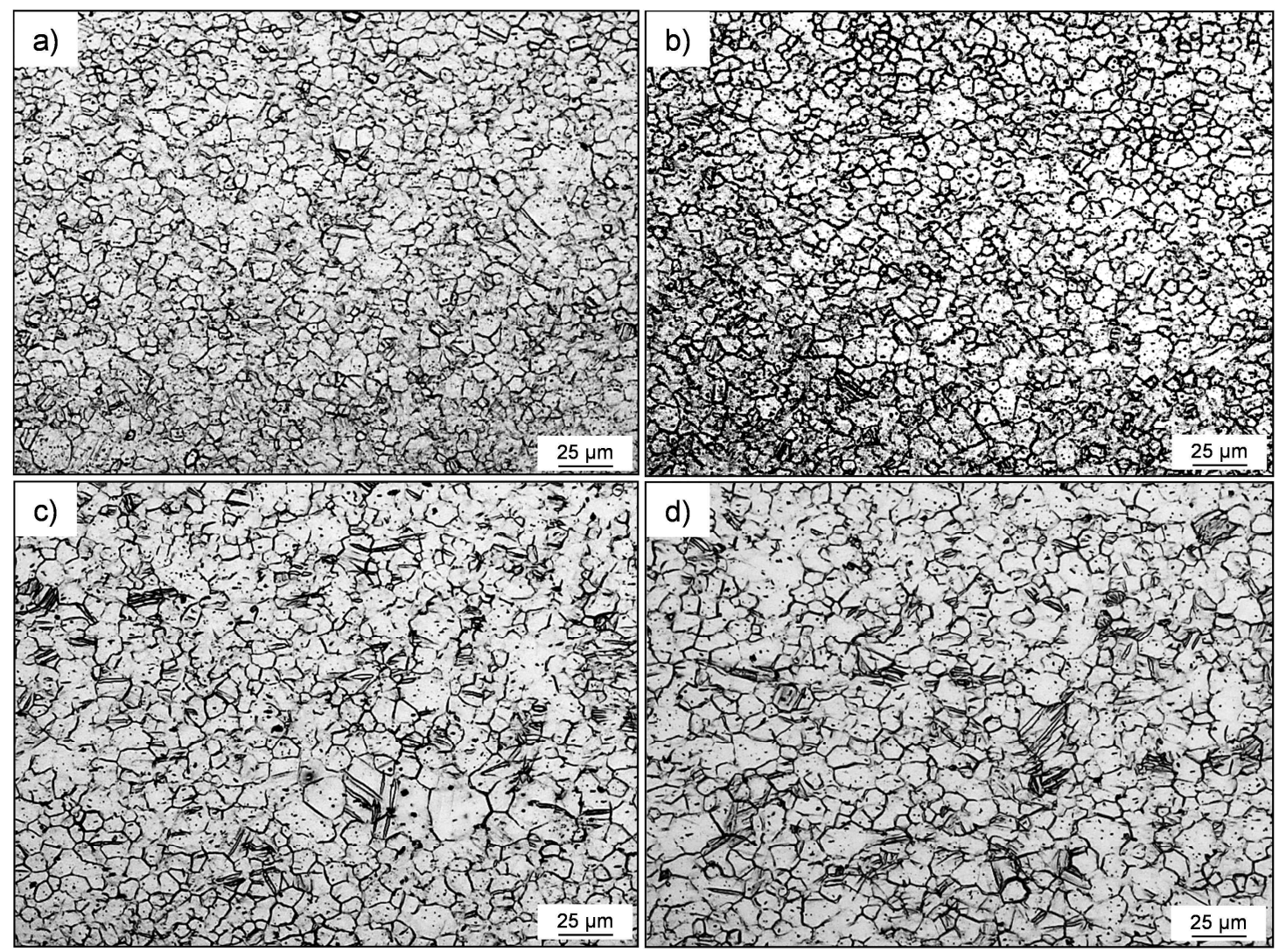

Fig. 7: Optical micrograph of the fractured specimens in the region of the crack at different bending conditions with different thicknesses $\left(90^{\circ}\right)$ : a) $\left.\mathrm{t}=0.6 \mathrm{~mm}, \mathrm{v}=0.1 \mathrm{~mm} / \mathrm{s} ; \mathrm{b}\right) \mathrm{t}=0.6 \mathrm{~mm}$, $\mathrm{v}=10 \mathrm{~mm} / \mathrm{s} ; \mathrm{c}) \mathrm{t}=2.0 \mathrm{~mm}, \mathrm{v}=0.1 \mathrm{~mm} / \mathrm{s} ; \mathrm{d}) \mathrm{t}=2.0 \mathrm{~mm}, \mathrm{v}=10 \mathrm{~mm} / \mathrm{s}$. 


\section{Summary}

The following conclusions were derived from this investigation:

1. With increasing sheet thickness, the force maximum $F_{\max }$ rises and the corresponding bending angle $\alpha_{c}$ remains constant at $0^{\circ}$ and $90^{\circ}$ deformation. The increase of the bending force is a result of a rising moment of resistance to bending, when the thickness is increased. In addition, higher amount of mechanical twinning is present which is also a function of the initial grain size.

2. The loading rate has no significant influence on $F_{\max }$ and $\alpha_{c}$ neither at $0^{\circ}$ nor at $90^{\circ}$ deformation. However, the loading rate dependent spread of the $\alpha_{c}$ values decreases considerably above $1.0 \mathrm{~mm}$ sheet thickness.

3. The punch diameter has no significant influence on $\alpha_{\mathrm{c}}$ and $\mathrm{F}_{\max }$ at $0^{\circ}$ and $90^{\circ}$ deformation.

4. At higher sheet thicknesses, $\mathrm{F}_{\max }$ in $90^{\circ}$ sample extraction direction is lower than in $0^{\circ}$ sample extraction direction, whereas the corresponding bending angle $\alpha_{c}$ is independent of the sheet thickness.

\section{Acknowledgements}

The authors wish to acknowledge the financial support of the SMiLE project ("Systemintegrativer Multi-Material-Leichtbau für die Elektromobilität", project number: 03X3041O) by the German Federal Ministry of Education and Research. They also wish to thank Ms. Irena Diegel for the experimental support.

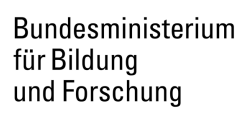

\section{References}

[1] B.L. Mordike, T. Ebert, Magnesium: Properties - applications - potential, Mater. Sci. Eng. A 302 (2001) 37-45.

[2] F. Berge, L. Krüger, H. Ouaziz, C. Ullrich, Influence of temperature and strain rate on the flow stress behavior of twin-roll cast, rolled and heat-treated AZ31 magnesium alloy, Trans. Nonferr. Met. Soc. 25 (2015) 1-13.

[3] M. Ullmann, F. Berge, K. Neh, R. Kawalla, Development of a rolling technology for twin-roll cast magnesium strips, Metalurgija 54 (2015) 711-714.

[4] K. Neh, M. Ullmann, M. Oswald, F. Berge, R. Kawalla, Twin roll casting and strip rolling of several magnesium alloys, Mater. Today Proc. 2 (2015) 45-52.

[5] C. Ullrich, F. Schwarz, A. Franke, T. Marr, D. Rafaja, L. Krüger, J. Freudenberger, The preparation of magnesium specimens for EBSD using ion polishing, Pract. Metallogr. 5 (2012) 290-304.

[6] J. Koike, R. Ohyama, T. Kobayashi, M. Suzuki, K. Maruyama, Grain-boundary sliding in AZ31 magnesium alloys at room temperature to $523 \mathrm{~K}$, MATERIALS TRANSACTIONS 44 (2003) 445451.

[7] J. Koike, New deformation mechanisms in fine-grain Mg alloys, Mater. Sci. Forum 419-422 (2003) 189-194.

[8] J. Koike, Enhanced deformation mechanisms by anisotropic plasticity in polycrystalline $\mathrm{Mg}$ alloys at room temperature, Metall. Mat. Trans. A 36 (2005) 1689-1696. 
[9] B. Li, S.J. Horstemeyer, A.L. Oppedal, P.T. Wang, M.F. Horstemeyer, Inverse Strain Rate Sensitivity of Bendability of an AZ31 Sheet in Three-Point Bending, In: Hort, N., Mathaudhu, S.N., Neelameggham, N.R., Alderman, M. (eds.), Magnesium technology 2013: Proceedings of a symposium sponsored by the Magnesium Committee of the Light Metals Division of the Minerals, Metals \& Materials Society (TMS), held during TMS 2013 Annual Meeting \& Exhibition, San Antonio, Texas, USA, March 3-7, 2013, John Wiley \& Sons Inc, Hoboken, New Jersey, 2013, pp. 127-131.

[10] J. Kim, H. Ryou, D. Kim, D. Kim, W. Lee, S.-H. Hong, K. Chung, Constitutive law for AZ31B $\mathrm{Mg}$ alloy sheets and finite element simulation for three-point bending, International Journal of Mechanical Sciences 50 (2008) 1510-1518.

[11] F. Berge, L. Krüger, M. Ullmann, C. Krbetschek, R. Kawalla, Anisotropy of the mechanical properties of twin-roll cast, rolled and heat-treated AZ31 as a function of temperature and strain rate, Mater. Today Proc. 2 (2015) 233-241.

[12] J.W. Christian, S. Mahajan, Deformation twinning, Prog Mater Sci 39 (1995) 1-157.

[13] L. Jiang, J.J. Jonas, A.A. Luo, A.K. Sachdev, S. Godet, Twinning-induced softening in polycrystalline AM30 Mg alloy at moderate temperatures, Scripta Materialia 54 (2006) 771775 .

[14] F. Berge, L. Krüger, C. Ullrich, Forming limit diagrams of twin-roll cast, rolled and heattreated AZ31 as a function of temperature and loading rate, Mater. Sci. Eng. A 614 (2014) 2735.

[15] B. Li, Z. McClelland, S.J. Horstemeyer, Geometrically necessary twins in bending of an AZ31 sheet, In: Manuel, M.V., Singh, A., Alderman, M., Neelameggham, N.R. (eds.), Magnesium Technology: Proceedings of a symposium sponsored by Magnesium Committee of the Light Metals Division of The Minerals, Metals \& Materials Society (TMS), held during TMS 2015, 144th Annual Meeting \& Exhibition, March 15-19, 2015, Walt Disney World, Orlando, Florida, USA, Wiley-VCH, Hoboken, New Jersey, 2015, pp. 127-132. 